ARTICLE

\title{
Empowering Growth in Pakistan?
}

\author{
Karin Astrid Siegmann ${ }^{1}$ (D) Hadia Majid ${ }^{2}$ (D)
}

Accepted: 27 April 2021 / Published online: 18 June 2021

(C) The Author(s) 2021

\begin{abstract}
The SDGs' commitment to inclusive growth reflects an increasing international concern with the inclusiveness of macro-economic development. Yet, although research underscores that economic growth is not gender-neutral, gender dimensions remain a footnote to these debates. This article explores the connection between growth performance and gender inequalities in the case of Pakistan. The country's macroeconomic performance has been characterised as a case of 'growth without development'. More specifically, severe gender inequalities and women's marginalisation in international comparison have persisted even in phases of high GDP growth. This paradoxical situation offers a fertile context for the analysis of how empowering macro-economic growth has been and can be for women. We investigate how empowering growth has been for women in Pakistan by exploring aggregate data on sectoral growth and gendered employment. Our analysis does not suggest the straightforward win-win for growth and women's empowerment espoused in Pakistan's national policy vision. Rather, we find that women's employment is precarious-women are largely viewed as secondary earners engaging in distress sale of labour.
\end{abstract}

Keywords Employment · Empowerment · Gender equity · Inclusive growth · Pakistan

\section{Introduction}

The commitment to 'inclusive and sustainable economic growth' in the sustainable development goals (SDGs) reflects an increasing international concern with the inclusiveness of macro-economic development (see ADB 2014; G20 2018; OECD 2018; United Nations 2015; United Nations Development Programme 2017;

Karin Astrid Siegmann

siegmann@iss.nl

1 International Institute of Social Studies, Erasmus University Rotterdam (ISS), The Hague, The Netherlands

2 Lahore University of Management Sciences (LUMS), Lahore, Pakistan 
World Bank 2009). Hirway (2012: 65) considers growth performance inclusive if it includes poor and marginalised socio-economic groups as partners and beneficiaries in the growth process. M.H. Khan's (2012a, b) narrower definition of inclusive growth focuses on the growth-employment nexus. According to M.H. Khan (2012a, b: 16), inclusive growth is "[...] growth that is both sustainable and broad-based in terms of employment opportunities'.

South Asian countries have seen a trend of declining employment intensity of economic growth over the past decades (Islam 2019). Most detailed investigations of the inclusiveness of growth in the region have focused on India. ${ }^{1}$ While Abubakar and Nurudeen's (2019) analysis establishes a negative relationship between Gross Domestic Product (GDP) changes and unemployment, authors focusing on formal employment, in contrast, find jobless and unequalising growth in India, especially in the post-reform period after 1990 (e.g. Tejani 2016; Kannan and Raveendran 2009). Employment elasticity of growth in India's informal sector almost doubling that in the formal sector reflect the ongoing trend towards informalisation (Hill 2014: 227).

Gender dimensions have, by and large, been a footnote to the literature on inclusive growth. ${ }^{2}$ This is despite the fact that research underscores that economic growth is not gender-neutral (Seguino 2020). In India, the strong growth performance during the past three decades, alongside improvements in girls' access to education and better infrastructure, could be assumed to increase women's opportunities for paid work. Yet, female labour force participation has actually declined, especially in rural areas. Desai and Joshi (2019: 70) explain this with 'the crowding out of women in agriculture where land fragmentation has led to a reduction in both the size of farms and the demand for labour'. In urban India, the rapid growth of information and technology-enabled services and business process outsourcing since the 1990s translated into formal jobs for educated female workers. While the small size of the sector implies that this form of gender-inclusive growth 'is only a reality for very few women' (Hill 2014: 233), the post-reform increase in the wealth of urban households and the emergence of dual-earner family structures have simultaneously led to an expansion of poorly paid and precarious domestic work in private households (Hill 2014: 234).

This article explores the connection between economic growth performance and gender inequalities in Pakistan, a country largely ignored in the scholarly literature on inclusive growth. Pakistan's macro-economic performance has been characterised as a case of 'growth without development' (Easterly 2001). More specifically, severe gender inequalities in international comparison have persisted even in phases of high GDP growth. This paradoxical situation offers a fertile context for the analysis of how empowering macro-economic growth has been and can be for women.

Pakistan's Vision 2025 connects a policy commitment to greater gender equality with inclusive growth. It prioritises a 'good quality of life and high living standard for all citizens across regions, gender' and to 'achieve an annual average growth rate

\footnotetext{
${ }^{1}$ Islam (2014) writing on the employment intensity of Bangladesh's growth performance is a notable exception.

${ }^{2}$ Kabeer (2012) and Niimi (2009) are notable exceptions here.
} 
of seven to eight per cent that is inclusive' as its first two objectives (Planning Commission 2014).

These commitments respond to the multiple inequalities and the increasing polarisation that characterise the South Asian country. Rather than indicating its economic strength, Pakistan's relatively high average income of current USD 1461 in 2017 (World Bank 2020) reflects these inequalities. This is illustrated by the high incidence of poverty of a quarter of the population at the national poverty line in 2015 (World Bank 2020) that persisted even during periods of high growth since the turn of the millennium. Similarly, despite international and national commitments (for example, as a signatory to the Convention on the Elimination of All Forms of Discrimination against Women (CEDAW), and with a National Policy for Development and Empowerment of Women in place since 2002), Pakistan is characterised by wide gender gaps and marginalisation of women in the areas of health, education and labour market opportunities. This is reflected in Pakistan's extremely low ranking in the Global Gender Gap Index 2020, as the world's third-worst country in terms of equitable division of resources and opportunities among men and women (World Economic Forum 2019: 9).

For Kabeer (2005: 13-15), women's access to resources represents one of three pillars of their empowerment. She underlines that gender equality and women's empowerment are intrinsic goals, explicitly valued as ends in themselves rather than as instrumental for the achievement of other policy goals (Kabeer 2005: 13). Kabeer (2005: 13) understands empowerment as '[...] the processes by which those who have been denied the ability to make choices acquire such an ability'. In order to exercise strategic choices, the agency to challenge power relations, resources that can serve as the medium through which agency is exercised as well as the actual achievement of the types of lives that people want are required (Kabeer 2005: 13-15). Thus, in order to study whether macro-economic growth has been associated with empowerment for women in Pakistan, we examine the nexus between growth and gendered employment. We consider the latter as a potential resource to strengthen people's agency (Kabeer 2005: 18).

We conduct an exploratory data analysis (Smith-Miles 2011) of published data from 1990 to 2017. The gendered sectoral employment figures are derived from the Pakistan Labour Force Survey of the Pakistan Bureau of Statistics (PBS), while the sectoral growth statistics have been provided by the State Bank of Pakistan (SBP). ${ }^{3}$ The results of our exploration show that while positive economic growth rates are often assumed to go hand in hand with rising employment levels and income earning opportunities for women (World Bank 2011: 152), growth and gender equality in Pakistan are not systematically correlated.

A first glance at related indicators suggests that while female labour force participation (FLFP) has increased steadily until 2014, women's wage employment has been volatile, while female self-employment often shows counter-rotating trends in relation to GDP growth (Fig. 1).

\footnotetext{
3 The definitions of major economic sectors in our analysis follow the Pakistan Standard Industrial Classification (PSIC) (see, e.g. PBS 2010).
} 


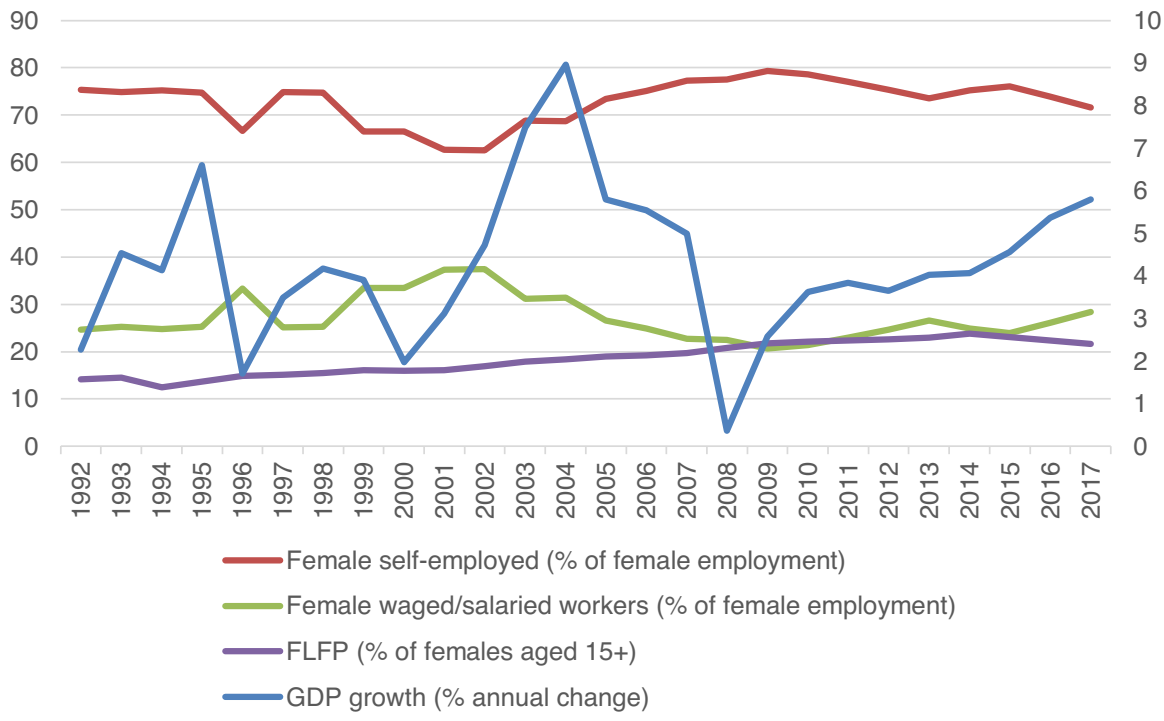

Fig. 1 GDP growth and female employment in Pakistan, 1990-2017 Sources: Ministry of Finance (2018), PBS (2018), SBP (2018), World Bank (2020). Note: real GDP growth is measured on the vertical axis represented on the right of the figure, while the employment shares are measured on the vertical axis on the left. Years in this and other figures and tables refer to the start of the fiscal year (FY) (e.g. 1990 refers to FY 1990-91)

This volatility in female wage employment as well as the counter-rotating trends of female self-employment reflect that women in Pakistan are largely viewed as secondary earners engaging in distress sale of labour. We explore this hypothesis further by examining trends in growth and employment at the sectoral level.

In the following section, we outline theoretical predictions and empirical findings on the link between economic growth performance, gendered employment and women's empowerment. Informed by these perspectives, we discuss empirical trends in the growth-gendered employment nexus in Pakistan since the economy was liberalised substantially during the 1990s. Based on this, in the concluding section, we formulate tentative implications for policies aimed at 'empowering growth' in Pakistan.

\section{Understanding Empowering Growth-A Brief Review}

\subsection{Transmission Channels of Growth to Gendered Employment}

M.H. Khan's (2012a, b) notion of inclusive growth that underlines its association with broad-based employment creation is based on the acknowledgement that while macro-economic growth might be an important factor in providing employment opportunities for women and men, it is not a sufficient condition (Berg 2013: 47-48). Rather, the employment intensity of growth matters for whether growth 
translates into employment opportunities (Osmani 2006). Moreover, this process of translation is often gender-specific. Such a gendered growth-employment nexus is reflected in different growth elasticities of employment, i.e. the rate at which employment grows when GDP increases by one percentage point. Kapsos (2005: 15) finds higher elasticities for women in South Asia than for men, especially during the 1990s. He offers three possible explanations for higher female elasticities: i. a secular process of catching up of women's employment, ii. greater sensitivity of women's employment to the economic cycle and/or iii. the concentration of female jobs in more labour-intensive sectors (Kapsos 2005: 9). ${ }^{4}$ Kabeer (2016) supports Kapsos' last interpretation when she emphasises the role of sectoral segregation for growth effects on gendered employment. She concludes that: '[...] it is the pattern, rather than the pace, of growth which determines the gender distribution of economic opportunities' (Kabeer 2016: 316).

Kapsos' first explanation can be related to the hypothesis of a U-shaped relationship between economic growth and female labour force participation first proposed by Boserup (1970). Building on dualist development models, she argued that men's privileged access to education and technology would displace women from the labour force during early stages of development. With further development, women gain access to education and technology with this process intersecting with the gender division of reproductive labour, i.e. work for the daily maintenance of the labour force as well as for the perpetuation of social systems (Benería and Sen 1981: 290). When the main site of production shifts from the home to the factory, women-who are considered 'homemakers' in many societies - are at a disadvantage in accessing employment. Yet, the types of jobs offered as well as the social norms mediating gender-specific employment change over time and enable women to participate (Blau 2014: 198-199; Tam 2011: 140-141). This 'feminisation U'-with the term mirroring an initial decline and later increase of female labour force participationhas been supported in cross-country, but-more importantly-also in time-series analyses (Çağatay and Özler 1995; Goldin 1994; Olivetti 2013; Tam 2011). Kazi (1999: 392) finds support for it for a cross section of women in Pakistan.

\footnotetext{
4 Although not the focus of this contribution, the reverse effect, i.e. the role of gender inequality in employment for growth performance, has been investigated too, acknowledging that ' $[\mathrm{t}] \mathrm{here}$ is thus a two-way causality between macroeconomic variables and gender equity' (Seguino and Grown 2006: 1081). Klasen and Lamanna (2009: 91) find that 'gender gaps in education and employment considerably reduce economic growth'. Mitra, Bang and Biswas (2015) confirm this finding on the basis of a panel regression of 101 countries in the period between 1990 and 2000, while Pervaiz, Chani, Jan and Chaudhary (2011) find support for it in the context of Pakistan. Their index of gender inequality that addresses dimensions of health, education, employment has a negative and significant impact on economic growth. This win-win scenario has not gone without critique. For instance, for the context of Asian economies, Seguino (2000) argues that gender wage inequality has actually stimulated growth. She shows how the segregation of lower-paid women in export industries helped to keep export prices low and hence to increase competitiveness.
} 


\subsection{Access to Paid Jobs not Necessarily Empowering}

Similar to the complex transmission of economic growth performance into gendered employment, access to jobs alone is not necessarily empowering. Summarising earlier studies, Seguino (2016: 16) asserts that employment is a key mechanism for promoting gender equality, which in turn can leverage change in other domains. Both she and Kabeer (2016: 311) highlight that the quality of jobs also matters: 'Women have made clear gains in terms of the quantity of employment generated by neoliberal patterns of growth, but their gains are far less clear in relation to its quality'. Overall, it has been pointed out that informal and formal institutions, such as social norms as well as the legal and political context, have a crucial role in mediating employment effects on women's empowerment (Elson 1999; Kabeer 2016; Van Staveren 2013). A high growth elasticity of employment might be triggered by the take up of 'survival' jobs-jobs taken out of dire economic need rather than 'career' jobs, i.e. jobs 'upon which one could support a family and develop a sense of selfworth and dignity' (Chun 2016: 176). Such distress sale of labour has been labelled as 'added worker effect'. It implies that so-called secondary workers, often women and young people, take up jobs during recessions and so their labour force participation displays a counter-cyclical trend. That way, they compensate for the losses in employment and/or earnings of other household members who are affected by the business cycle or macro-economic shocks (Borjas 2010: 70-71). Agarwal (2020: 22) therefore insists on the conceptual distinction between labour force participation and sustainable livelihoods, arguing that a focus on labour force participation alone does not capture vulnerability to poverty. A. Khan's (2007: 7) observation that, by and large, Pakistani women work out of economic need is in line with such distress employment. This is perhaps best exemplified by their poorer representation in formal employment and their comparatively higher concentration in informal employment where there is arguably greater flexibility in terms of entry into and exit from the labour market. In 2015, women's informal employment as a share of their total employment hovered at around 92 per cent compared to 80 per cent for men (ILO 2018: 88).

N. Ahmed and Hyder (2006: 35) find that, during the period of 1976-2005, per capita income in Pakistan was negatively associated with female labour force participation as well as the negative association of the share of women's self-employment with GDP growth since the turn of the millennium (Fig. 1) may be interpreted as further support for this view. Moreover, Sabir and Aftab (2007) provide evidence that increased employment possibilities for women in Pakistan might be directly related to their subordinate position in the labour market and may not be empowering them. They point out that the increase in female labour supply during high growth periods actually translated in widening the gender pay gap (Sabir and Aftab 2007: 876).

In contrast, Sen (1987) assumed an increase in women's bargaining power through autonomous income. He emphasised that outside earnings could give women a better bargaining position, a clearer sense of self-worth, as well as a higher perceived contribution to the household's economic position. Similarly, Kabeer (as cited in Pearson 2007: 204) argues that paid work enhances women's capacity to 


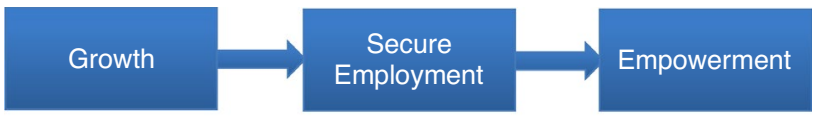

Fig. 2 Benchmark criterion for potentially empowering employment Source: own design

exercise choices and gain some control over different aspects of their lives. Others have pointed out that these empowering effects are mediated by the expansion of women's mobility and social networks that are associated with paid employment (World Bank 2011: 155-156). Kabeer (2005: 18-20) supports Sen's theoretical claim with empirical research. She finds that access to paid work in many countries has increased women's agency both in self- as well as waged employment in agriculture and-especially-in non-agricultural sectors.

This link between secure jobs and an improved status for women has been supported in the Pakistani context as well (Arshad 2011; Khattak 2002; Mason and Smith 2003; Sathar and Kazi 2000). Seguino and Grown (2006: 1083) emphasise that secure earnings are necessary to improve women's power to negotiate for an equitable distribution of household resources and unpaid labour. In her review of the body of research on women's employment in Pakistan, A. Khan (2007: 14) comes to a similar conclusion. Quoting Sathar and Kazi (1990: 69), she argues that prospects for change in women's status lie not in the expansion of employment per se, but rather in job opportunities that are valued by society. This often implies employment outside the home, in the formal sector. Unfortunately, international evidence shows that women workers are overrepresented in insecure jobs and home-based work and the same holds for Pakistan where only one in three women works out of the home in urban Pakistan, the vast majority of them being on casual contracts within the manufacturing sector (Majid 2020). This is steeped in the presumption that women's earnings are supplementary, while men are assumed to have a right to regular jobs and pay (Seguino and Grown 2006: 1086) as well as the more coveted public sector jobs which carry with them both influence as well as significant job security. While jobs in public administration and defence, for instance, accounted for only 2.4 per cent of the total labour force in Pakistan, women held merely 2 per cent of these jobs in 2014-2015 (PBS 2015).

On the basis of this controversy, we develop a benchmark criterion for potentially empowering employment, namely employment that is characterised by more regular, formal conditions (Fig. 2). This criterion is in line with Esquivel's (2017: 549) argument that: '[g]rowth can indeed be gender equitable if it generates protected, well-paying and equal-paying jobs for women, who are able to take up employment without jeopardising their wellbeing or that of those they care for'. ${ }^{5}$ We argue that, while access to paid employment might be an important factor for women's empowerment, it is unlikely to be sufficient to widen their scope of strategic life

\footnotetext{
${ }^{5}$ Due to data constraints, the empirical analysis presented in this article does not consider that women's employment can occur at the expense of their unpaid care and domestic chores, a point underlined by Esquivel (2017).
} 
choices. The conditions at work are crucial as well, with more well-paid, regular and formal forms of employment having greater potential for providing women with resources to strengthen their agency. Seguino (2016: 18) assumes that industrial sector employment is characterised by a higher likelihood of meeting these conditions due to the better remuneration and greater possibility of access to social security. Thus, in order to understand whether growth has been empowering for women, one has to look at the type and nature of employment.

\section{Exploring the Growth-Gendered Employment Nexus in Pakistan}

Based on the criteria for 'empowering growth' derived above, i.e. growth that is associated with an increase in secure employment for women, this section examines trends in overall and sectoral GDP growth, as well as associated female and male employment patterns. Pakistan's average growth rate of 4.5 per cent between 1990 and 2017 seems impressive, yet the performance has been rather volatile (Fig. 1). ${ }^{6}$ Looking at sectoral growth rates, we again find average growth rates in excess of 4.7 per cent for industry and services between 1990 and 2017 (Table 1 in appendix). During the same time period, agriculture, however, averaged growth rate of 3.2 per cent, with wide year-to-year fluctuations during the last three decades.

\subsection{Low Agricultural Growth Accompanied by Feminisation of Labour Force}

The agriculture sector contributed about 19.5 per cent to GDP and is a mainstay for employment, employing around 39 per cent of the total labour force in 2017 (Danish et al. 2017; PBS 2018: 26). It has also seen heavy state investment with considerable government subsidies for various inputs into the agricultural production process - irrigation, seeds, pesticides, fertilisers - along with related infrastructure over the decades (Danish et al. 2017; Ahmed and Asif 2016). While public fixed investment in agriculture nearly doubled in absolute terms between 2009 and 2014, real growth in public fixed investment varied widely in the same time period and was negative in 2013 and 2014 (Ahmed and Asif 2016). At the same time, growth in the sector has shown a declining trend for the past three decades and productivity has been low due to falling investments and particularly water-related challenges (Fig. 4, Finance Division 2010). Although agriculture grew at an average of almost five per cent between 1990 and 1996, a yearly breakdown reveals that this period saw both the all-time high and low of 11.7 and -5.3 per cent annual sectoral growth. Further, the comparatively lower average growth rate of agriculture relative to the other two major sectors for the 27-year period examined in this paper may in part be attributed to the poor harvest of 1993, and the extreme drought between 1998 and 2002, which reached its peak in 2000-2001 (Majid and Zahir 2013: 15). Other issues facing the

\footnotetext{
${ }^{6}$ In addition, Balagamwala and Gazdar (2011: 3) also remind us that 'The main turning point in economic growth coincided with significant inflow of military aid, development assistance and concessional lending'.
} 
Table 1 Real GDP growth in Pakistan by main sector, 1990-2017 (annual \% change)

\begin{tabular}{|c|c|c|c|c|}
\hline & Agriculture & Industry & Services & Total \\
\hline 1990 & 4.96 & 6.86 & 5.21 & 5.57 \\
\hline 1991 & 9.50 & 7.73 & 6.76 & 7.71 \\
\hline 1992 & -5.29 & 5.51 & 4.63 & 2.27 \\
\hline 1993 & 5.23 & 4.54 & 4.20 & 4.54 \\
\hline 1994 & 6.57 & 0.69 & 4.80 & 4.13 \\
\hline 1995 & 11.72 & 4.72 & 4.99 & 6.60 \\
\hline 1996 & 0.12 & -0.33 & 3.61 & 1.70 \\
\hline 1997 & 4.52 & 6.12 & 1.64 & 3.49 \\
\hline 1998 & 1.95 & 4.92 & 4.99 & 4.18 \\
\hline 1999 & 6.09 & 1.27 & 4.15 & 3.91 \\
\hline 2000 & -2.18 & 4.13 & 3.09 & 1.97 \\
\hline 2001 & 0.10 & 2.70 & 4.76 & 3.11 \\
\hline 2002 & 4.15 & 4.24 & 5.22 & 4.73 \\
\hline 2003 & 2.43 & 16.26 & 5.84 & 7.48 \\
\hline 2004 & 6.49 & 12.12 & 8.49 & 8.96 \\
\hline 2005 & 6.30 & 4.10 & 6.50 & 5.80 \\
\hline 2006 & 3.42 & 7.73 & 5.58 & 5.54 \\
\hline 2007 & 1.81 & 8.47 & 4.94 & 4.99 \\
\hline 2008 & 3.50 & -5.21 & 1.33 & 0.36 \\
\hline 2009 & 0.23 & 3.42 & 3.21 & 2.58 \\
\hline 2010 & 1.96 & 4.51 & 3.94 & 3.62 \\
\hline 2011 & 3.62 & 2.55 & 4.40 & 3.84 \\
\hline 2012 & 2.68 & 0.61 & 5.13 & 3.65 \\
\hline 2013 & 2.69 & 4.45 & 4.37 & 4.03 \\
\hline 2014 & 2.13 & 5.18 & 4.36 & 4.06 \\
\hline 2015 & 0.15 & 5.7 & 5.72 & 4.56 \\
\hline 2016 & 2.07 & 5.4 & 5.47 & 5.37 \\
\hline 2017 & 3.81 & 5.80 & 6.43 & 5.79 \\
\hline Average & 3.24 & 4.79 & 4.78 & 4.45 \\
\hline
\end{tabular}

Source: Ministry of Finance (various years), PBS (2019), SBP (2018)

agriculture sector resulting in low productivity relate to issues of land fragmentation and the resulting inapplicability of modern technologies, water-logging and salinity which not only reduce productivity on cultivated land, but also lead to loss of land available for cultivation, low total factor productivity, inadequate agricultural extension services and agricultural inputs, among others (A. Khan 2012a, b; Murgai et al. 2001).

Despite its relatively low contribution to GDP and its poorer growth performance, the largest absolute number and relative share of both employed men and women 
60.00

50.00

40.00

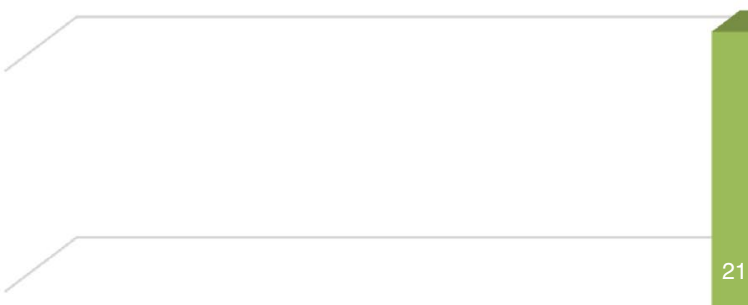

30.00

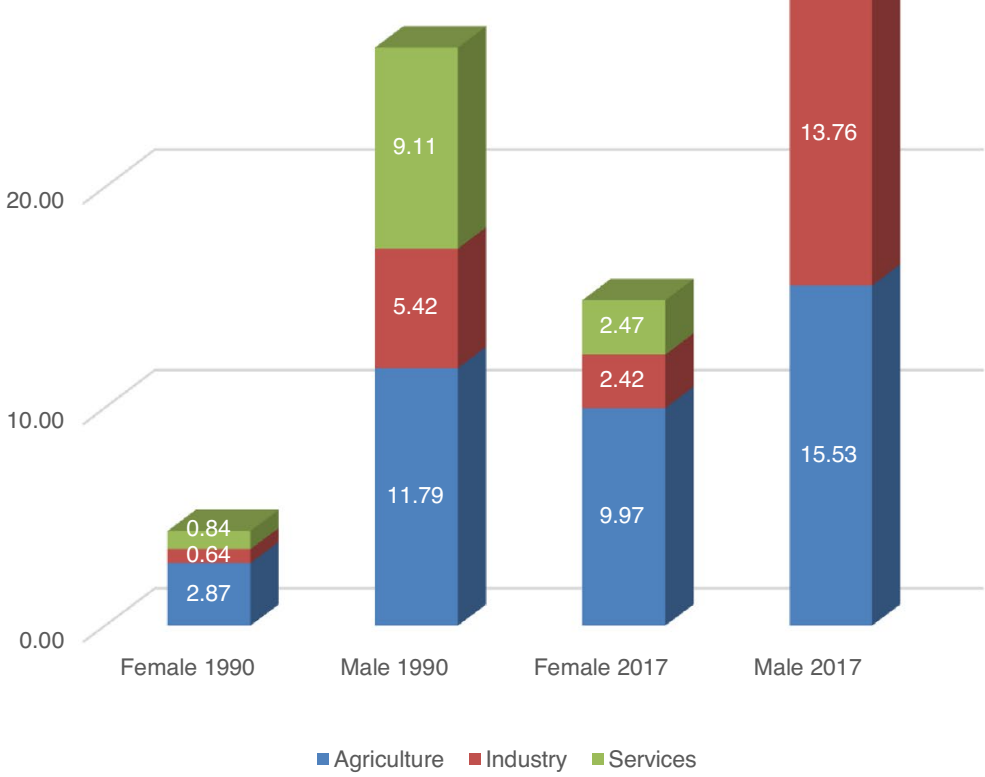

Fig. 3 Employment by main industry and gender, 1990 and 2017 (millions). Source: PBS (various years). Note: employment figures refer to employment of females and males aged 10 years and older.

were concentrated in the agricultural sector in 1990 (Fig. 3). ${ }^{7}$ In 2017, this still holds for female employment, while the service sector has overtaken agriculture as men's

\footnotetext{
7 The Pakistan Labour Force Survey captures both formal and informal employment.
} 


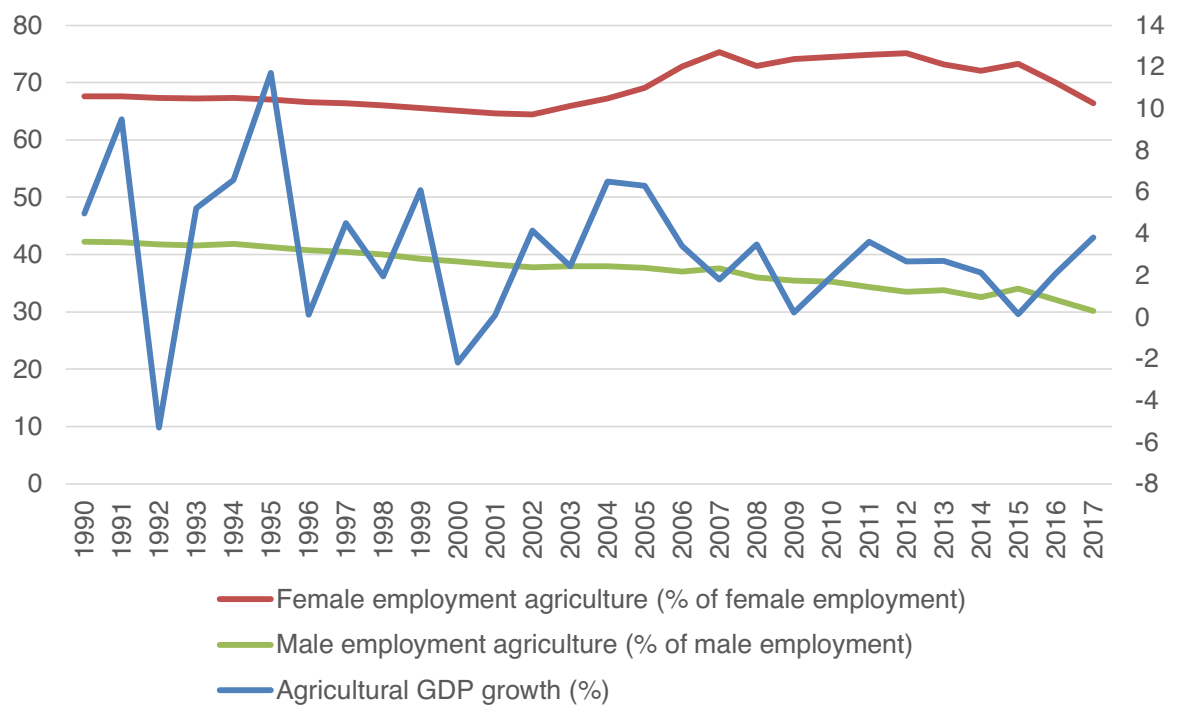

Fig. 4 Growth and gendered employment in Pakistan's agriculture, 1990-2017 Sources: Ministry of Finance (various years), PBS (2019), SBP (2018), World Bank (2020). Note: the shares of agricultural employment refer to employment of females and males aged 15 years and older. From 2005 onwards, agriculture includes cotton ginning, subsumed under industry before. Agricultural GDP growth is measured on the vertical axis represented on the right of the figure, while the employment trends are measured on the vertical axis on the left

main employer. Throughout, the proportion of employed women working in agriculture was at a significantly higher level than that for men (Fig. 4). The concentration of women in agriculture compared to men is unsurprising given the restrictions on women's mobility and their lower education levels.

Social norms in large parts of South Asia dictate that women's role be restricted to the reproductive sphere (Sathar et al. 1988: 415). Thus, even when women engage in formal economic activities, they are largely considered supplementary earners within the household and their labour market options remain restricted. Women's employment in agriculture is therefore considered more acceptable when performed on their own household's land as contributing family workers. Akram-Lodhi's 
(1996) study of the gender division of work in the Peshawar valley exemplifies that gender norms intersect with the class position of their household, with women's paid work being more common amongst peasant and-more generally-poorer classes.

The secular decline in the importance of male employment in agriculture in Fig. 4 reflects Boserup's (1970) ideas about men's preferential access to higher productivity manufacturing employment—or the broader set of labour market options available to them in comparison with women more generally. The trends shown in Fig. 4 reflect, however, that the concentration of both female and male employment in agriculture has declined until the turn of the millennium. Since the 2001 agricultural crisis, the trends diverge, though. For men, the significance of agricultural employment has continued to decline slowly, but persistently. For women, in contrast, one can observe a feminisation of agricultural employment in Pakistan, here understood as an increasing share of female agricultural employment in total female employment until 2012 after which this share declines again. In line with Boserup's (1970) prediction, A. Khan (2007: 5) relates the increased female labour force participation in rural areas to male out-migration towards the service and manufacturing sectors, as well as to the growth of cotton cultivation, demanding a vast seasonal female labour force for harvesting (Siegmann and Shaheen 2008).

The concentration of women in the agricultural sector is of particular concern as incomes in the industrial and service sectors typically tend to be higher when compared to those in agriculture and indicates that women are by and large stuck in the low-paying sector of the economy. The dominance of low- and unpaid as well as seasonal agricultural employment for women in Pakistan implies that, in terms of widening the scope of strategic life choice or empowerment, they are likely to gain least from their work.

\section{2 'Added Worker Effect' in Female Services Employment?}

In contrast to the declining significance of agriculture to GDP growth, rapid urbanisation, lower investment requirement in the service sector, and rapid growth in consumer financing have resulted in a structural shift in Pakistan's economy with services accounting for an increasingly higher share of GDP over the last few years (A. Ahmed and Ahsan 2011: 5; Husain 2007: 8). With the plethora of activities that come under the sector ranging from transport and communications to entertainment and recreational services, there is demand for unskilled, semi-skilled, as well as skilled labour within the sector (A. Ahmed and Ahsan 2011: 12).

This increased demand has largely benefitted men. Figure 3 reflects that, between 1990 and 2017, the service sector has become the largest employer of men. The upward trend in the concentration of male employment in the service sector since the 1990s has been the flipside of the decline in the proportion of men employed in agriculture (Figs. 4 and 5). During the same period, the relative importance of women's services employment increased during the 1990s, while it has seen a decline over the largest period since the turn of the millennium (Fig. 5).

Dominant gender norms have a mediating role here, since the services sector includes occupations deemed appropriate for women's employment, i.e. those that 


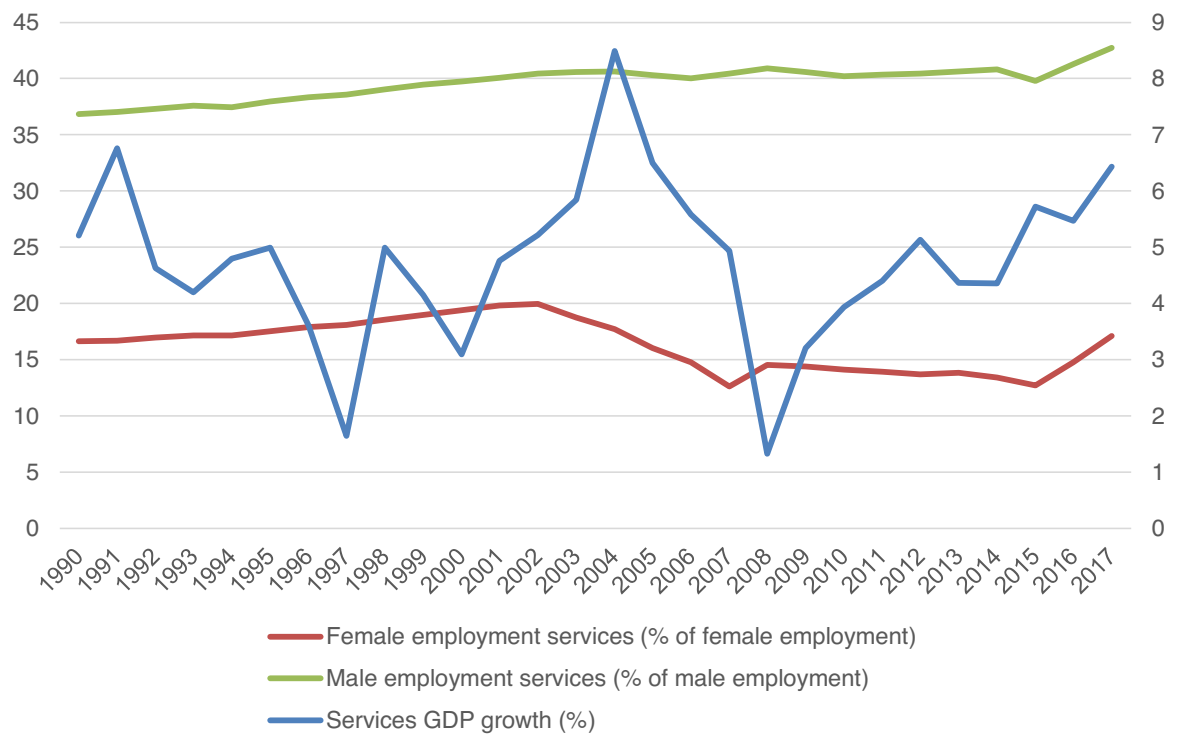

Fig. 5 Growth and gendered employment in Pakistan's service sector, 1990-2017 Sources: Ministry of Finance (various years), PBS (2019), SBP (2018), World Bank (2020). Notes: the shares of services employment refer to employment of females and males aged 15 years and older. Services GDP growth is measured on the vertical axis represented on the right of the figure, while the employment trends are measured on the vertical axis on the left

are perceived as extensions of their caring roles such as teaching and/or nursing as well as domestic work (see Jayaweera 1997: 250; A. Khan 2007: 4, 6). This is, for instance, reflected in the high concentration of female employment in community/ social and personal services at 14.6 per cent of the female labour force, third after agricultural and manufacturing employment (PBS 2018: 26).

It is interesting to note that the female share of employment in the services sector got a boost during a period of comparatively low sectoral growth from 1991-2000, yet, declined again when growth picked up after the turn of the millennium. This counter-cyclical pattern may point to an 'added worker effect', perhaps in response to formal employment losses during periods of structural adjustment (Kemal 1994: 905-907). The pattern can be related to Seguino's (2016: 18) suggestion that employment in the services sector represents some form of 'residual unemployment' due to the high concentration of informal work with low wages or profits. The takeup of paid services employment, for example in domestic work, as a compensation for income declines would also match the counter-cyclical trends in women's selfemployment mirrored in Fig. 1. 


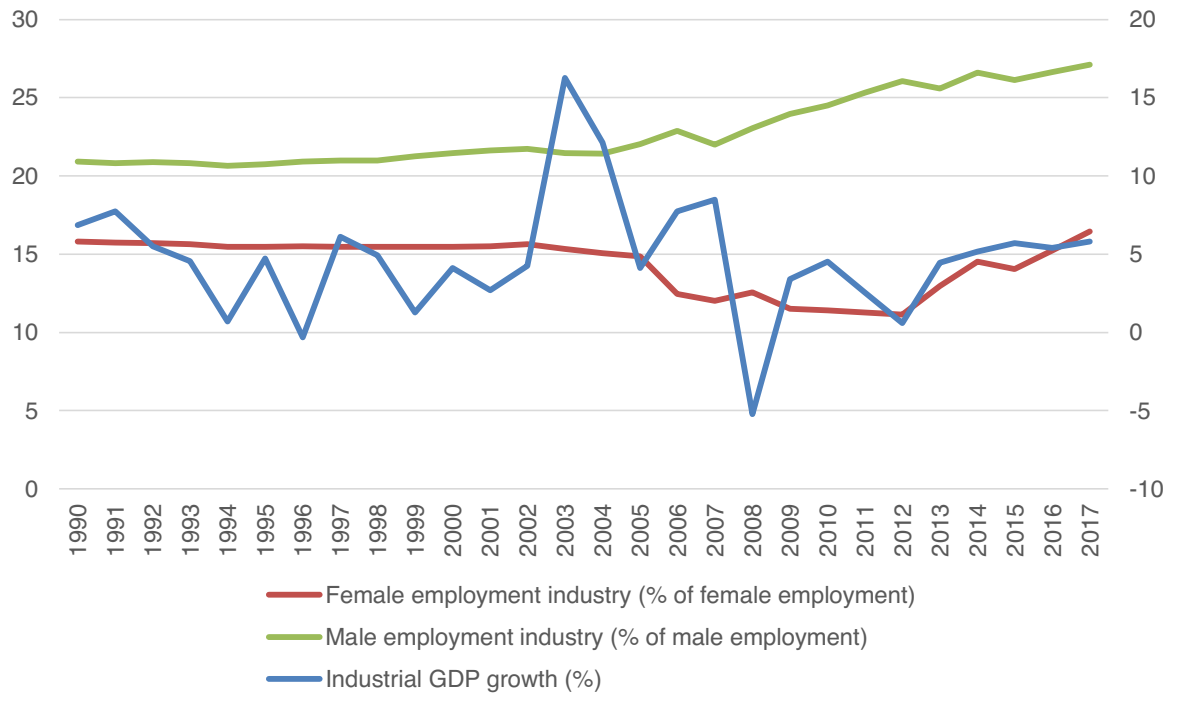

Fig. 6 Growth and gendered employment in Pakistan's industrial sector, 1990-2017 Sources: Ministry of Finance (various years), PBS (2019), SBP (2018), World Bank (2020). Notes: the shares of industrial employment refer to employment of females and males aged 15 years and older. Industrial GDP growth is measured on the vertical axis represented on the right of the figure, while the employment trends are measured on the vertical axis on the left

\subsection{Women Industrial Workers Bearing the Brunt of Recession}

Taking a closer look at the Pakistan's industrial growth rates between 1990 and 2017 , we see industry ${ }^{8}$ growing at remarkably high rates of over 12 per cent in 2003 and 2004, and the sector performing significantly better in most of the 2000s when compared to the 1990s (Fig. 6). While the dominant manufacturing sub-sector was plagued with issues of political instability, reduction in protection rates and inadequate investment during the 1990s leading to its lacklustre performance, the spike in consumer credit services and the resulting demand stimulus as well as an increase in exports due to reduced quota restrictions in textiles and clothing trade helped boost the sector's performance from 2000 to 2007 (Kemal 2006: 5). The subsequent energy crisis and the worsening law and order situation, which coincided with a slump in export demand due to the international financial and economic crises, forced a sharp decline in industrial growth, with rates hitting an all-time low of -5.2 per cent in 2008. Since then, although growth rates have improved overall 2010-2012 continued to mark lower growth rates primarily due to floods, as well as continued terror attacks in major cities which saw several production units move their operations to other countries in the region.

\footnotetext{
${ }^{8}$ The industrial sector comprises of mining and quarrying, manufacturing, electricity and gas as well as construction.
} 
As mentioned above, a greater proportion of employed men work in manufacturing when compared to women. This concentration has increased steadily since the turn of the millennium. Dominant gender norms that emphasise a caring and home-making rather than breadwinning role for women in Pakistan mediate female literacy rates that are substantially below those for men (Jayaweera 1997: 248). According to the 2014-2015 Pakistan Social And Living Standards Measurement, overall female literacy 10 years and older is 49 per cent as compared to 70 per cent for males (PBS 2016: xx).

While lower educational levels are likely to be one factor explaining the low numbers of women who find regular employment in the industrial sector, the same informal institutions that restrict women's mobility probably also form a far higher obstacle to enter formal employment in the manufacturing sector. As a result, a vast female workforce is employed under highly insecure conditions in home-based manufacturing (Akhtar 2011; Roots for Equity 2011).

Figure 6 also reveals that, while the 1990s saw the percentages of both employed women and men working in the sector holding fairly steady, from 2005 to 2012 , we see a divergence in the concentration of employed males and females in the sector. This period was marked by a decline in average growth rates in the industrial sector when compared to the preceding time span. In line with the higher growth elasticities that Kapsos (2005: 9) identified for women workers in South Asia, it seems then that greater sensitivity of women's employment to the economic cycle has translated into a situation in which female workers bear the majority of the burden during periods of decline vis-à-vis employment in the manufacturing sector. Possible explanations for these include a lack of unionisation of female employees as well as social norms that view men as primary breadwinners. Thus, given that in Pakistan, women's earnings are often viewed as supplementary, while men are considered to have a right to regular employment (Seguino and Grown 2006: 1086), in case of recessions the formal sector is likely to see employers laying-off women first so as to minimise the economic impact on households.

Yet, the pro-cyclical movements of the concentration of women's employment have also implied that discrete jumps preceded GDP growth performance, such as in 2002. One possible explanation is that the third-party contract system, which facilitates the recruitment of an indirect industrial workforce through labour contractors, actually increased the in-sourcing of a lower-paid female workforce, especially in the textiles and clothing sector. This in turn might have increased cost competitiveness with a lagged positive effect on industrial GDP.

As mentioned above, despite these caveats, industrial employment may offer the highest likelihood for regularity and non-wage benefits and, hence, for empowerment. In her cross-country study, Seguino (2016: 18-22) uses the ratio of shares of female and male employment in the industrial sector as a proxy for employment with greater potential for women's empowerment. While available data for Pakistan are patchy, the trend in this ratio reflected in Fig. 7 moves in tandem with the performance of industrial growth. Further disaggregation would be required to establish whether this parallel movement supports the proposition that a lower-paid female workforce has increased industrial cost competitiveness 


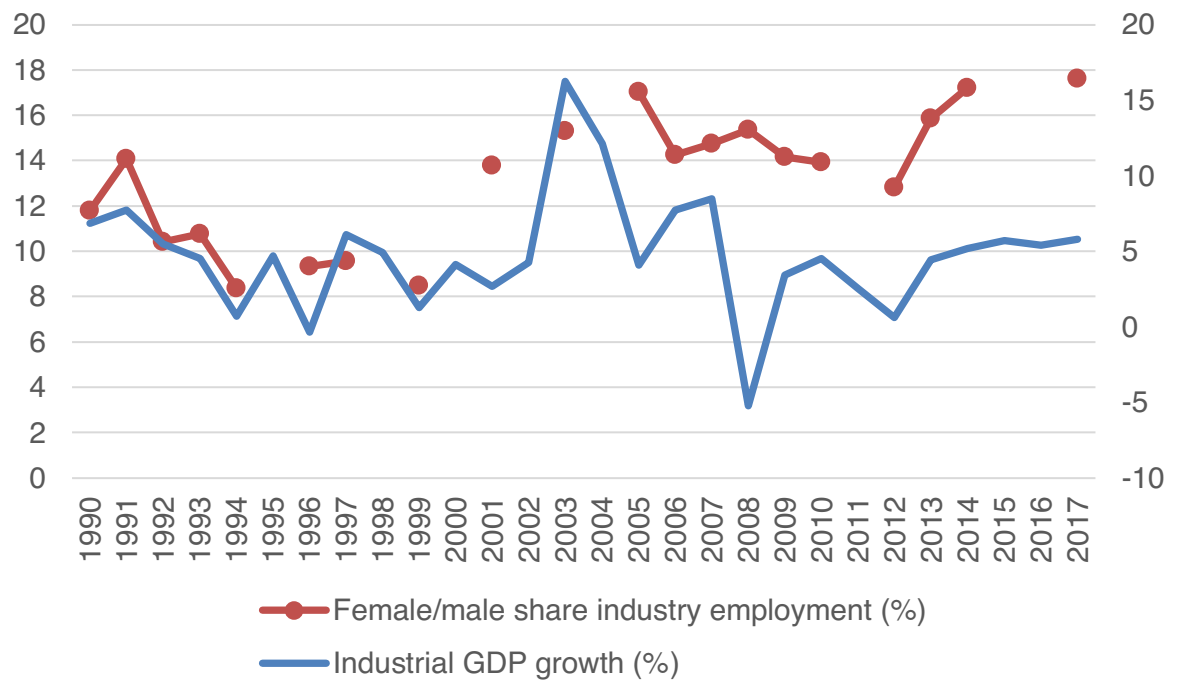

Fig. 7 Growth and ratio of female to male employment shares in Pakistan's industrial sector, 1990-2017 Sources: Ministry of Finance (various years), PBS (various years), SBP (2018). Note: the shares of industrial employment refer to employment of females and males aged 10 years and older. Industrial GDP growth is measured on the vertical axis represented on the right of the figure, while the employment share trends are measured on the vertical axis on the left

or whether the recent rise of the female share in industrial employment is promising for the potential for women's empowerment through access to more formal, industrial employment.

In these interpretations, one has to consider the underestimation of the informal workforce in published statistics also. Siddiqui et al. (2003: 157) point out that an expansion of female manufacturing employment has mainly taken place outside the regular factory workforce, for instance in the form of temporary and contract workers.

Overall, in our assessment of how empowering the employment-growth nexus has been for women in Pakistan, the trends presented above suggest bad news. Not only do women continue to be concentrated in agricultural and service sectors where women are more likely to engage in informal and/or casual jobs, but the counter-cyclical moves of women's employment concentration are likely to be associated with 'distress sales of labour'. In Sections. 1 and 2, we point out that formal, regular employment situations have the greatest potential to contribute to women's empowerment. While these conditions are most likely to be found in formal industrial employment, the concentration of women's employment in it has been volatile during the past decades. At the same time though, precarious informal and home-based manufacturing employment has dominated which is unlikely to mobilise the kind of resources that strengthen women's agency and allow them to make strategic life choices. 


\section{Discussion and Outlook}

\subsection{Discussion of Findings}

The explorative analysis presented in the previous section does not suggest a straightforward win-win situation for growth and women's empowerment that Pakistan's Vision 2025 aims for. Rather than proportionally 'trickling down' in the form of employment opportunities for men and women, even in periods of sustained economic growth such as during the first few years of the millennium, sectoral growth went in tandem only with the concentration of women's employment generation in manufacturing - and it seems this is corroborating women's subordinate role as secondary income earner rather being an expression of empowerment.

The dynamics in the agricultural sector support Boserup's (1970) prediction of a feminisation of agriculture in response to male out-migration from rural areas in response to higher-paying manufacturing jobs. Yet, the rising concentration of female employment in agriculture since the turn of the millennium until 2012 is probably not just compensating for the reduced significance of men in agricultural production. It might also reflect a higher demand for female labour for cash crop cultivation, such as cotton. Despite this increase in women's-paid and unpaid-employment during the last decade characterised by low agricultural growth, the precarious conditions that dominate women's agricultural employment in Pakistan imply that their jobs contribute to mere survival, rather than mediating greater empowerment. Siegmann and Shaheen (2008: 628) go further to argue that the success of Pakistan's cotton industry is at the expense of female agricultural workers' poor bargaining power.

In services, labour force survey data allow us to identify counter-cyclical trends in the concentration of female employment in the sector. These dynamics hint at 'added worker effects', with female service sector employment serving as a buffer during times of crises, implying distress sale of labour or what Seguino (2016: 18) labels 'residual unemployment'. Again, the gendered growth-employment nexus does not seem to augur well for women's empowerment.

Future research should both deepen and broaden our analysis based on the exploration of published growth and employment statistics. Corroborating and deepening the explanations of the patterns forwarded above through a more detailed econometric study of micro-data will help to further refine the gendered growth-employment nexus. Such a future analysis of Labour Force Survey data is to be complemented by an analysis of time-use data. Given that the normative construction of unpaid care or reproductive work as women's responsibility has a gender-unequal effect on the time available for remunerative work, without its incorporation, economic analysis will remain partial (Hirway 2015). While new international definitions of work now recognise unpaid care work (e.g. ICLS 2018), this is not yet reflected in the Pakistan Labour Force Survey. Against this backdrop, broadening the analysis with time-use data would enable a deeper understanding of the crucial intersection between various forms of productive and reproductive forms of work and the resulting (lack of) response to macro-economic impulses. 


\subsection{Policy outlook}

In line with Seguino and Grown (2006: 1082), our exploratory data analysis suggests that, if inclusive and gender-just growth is to become a reality, macro-economic strategies are required that shift the focus from being a "profit-led export-oriented economy to one that is wage-led-that is, an economy in which equity in incomes is compatible with growth'. However, the government's continued emphasis on a business-enabling environment (Ministry of Finance 2018: 1) does not augur well for inclusiveness. For instance, the expected growth impulses coming from Chinese foreign-direct investment are likely to be driven by access to Pakistan's large lowpaid workforce, besides the country's strategic location. If the potential effects on gender equality in employment and women's empowerment mirror the experience of export-led development a decade back, then inclusive or even empowering growth is unlikely to be the result of this strengthened Pakistan-China partnership in trade and investment.

At the level of labour markets, different governments have consistently focused on skills development as a major means to address people's unmet need for incomegenerating work and to stimulate growth. This agenda is underpinned by the assumption that shortcomings in workers' human capital endowment in the labour market represent obstacles for the achievement of the Government of Pakistan's decent work and inclusive growth agenda (Government of Pakistan 2004; ILO 2011; Ministry of Finance 2018: 2). Certainly, more human capital building of the labour force is required to enable women and men to reap the benefits of increased material prosperity. Yet, this investment needs to set in far earlier than vocational skills development. Not only do the low average levels of education in Pakistan in comparison with the region need to be addressed, but also the wide gender disparities. The provision of school meals and stipends for girls in other countries of the subcontinent have provided incentives to substantially increase girls' enrolment rates (Afridi 2011: 1636-1656; Chaudhury and Parajuli 2010: 3565-3583; Jha 2007: 84, 93, 101; Raynor and Wesson 2006: 1-12). The improvement of safe transport options as well as more flexible school hours might provide an additional boost for girls' schooling (Majid 2011).

However, it is questionable whether better and more gender-equal education alone addresses the root causes of the observed gender inequalities in the labour market. As we have seen above, prevalent gender norms play a powerful role for women and men's behaviour and mediate their position in the labour market. Increasing the visibility of women and their various contributions to the economy and wider society may be a crucial step here. This concerns a role for the media, but also for government and the private sector. Affirmative action, but also the provision of childcare facilities for employees is relevant policy option here.

Lastly, Pearson's (2007: 16) observation that ' $[\mathrm{t}]$ he norm for women in the majority world is economic engagement without regulation or protection' holds true for women in Pakistan, too. Due to the related insecurities, she argues that access to paid employment on its own will not empower women, but that it has to be coupled with state guarantees of a minimum income and affordable and quality public services (Pearson 2007: 16-17). The establishment of the Benazir Income Support 
Programme (BISP) in 2008 as an unconditional cash transfer for poor women may be viewed as a step in the right direction, yet the real 'paradigm shift' (Gazdar 2011) regarding social protection in Pakistan has yet to come.

\section{Appendix}

\section{See Table 1}

Acknowledgements Excellent research assistance by Syeda Warda Riaz is gratefully acknowledged.

Availability of Data and Material Data are based on published sources, see list of references.

\section{Declarations}

Conflict of interest The authors declare that they have no conflicts of interest.

Open Access This article is licensed under a Creative Commons Attribution 4.0 International License, which permits use, sharing, adaptation, distribution and reproduction in any medium or format, as long as you give appropriate credit to the original author(s) and the source, provide a link to the Creative Commons licence, and indicate if changes were made. The images or other third party material in this article are included in the article's Creative Commons licence, unless indicated otherwise in a credit line to the material. If material is not included in the article's Creative Commons licence and your intended use is not permitted by statutory regulation or exceeds the permitted use, you will need to obtain permission directly from the copyright holder. To view a copy of this licence, visit http://creativecommons.org/licen ses/by/4.0/.

\section{References}

Abubakar, J., and I. Nurudeen. 2019. Economic growth in India, is it a jobless growth? An empirical examination using Okun's law. The Indian Journal of Labour Economics 62 (2): 307-317.

Afridi, F. 2011. The impact of school meals on school participation: evidence from rural India. Journal of Development Studies 47 (11): 1636-1656.

Agarwal, B. 2020. Labouring for livelihoods: gender, productivity and collectivity. The Indian Journal of Labour Economics 63: 21-37.

Ahmed, A., \& Ahsan, H. (2011). Contribution of services sector in the economy of Pakistan. PIDE Working Papers 2011: 79. Islamabad: PIDE.

Ahmed, V., \& Asif, J. (2016). National study on agriculture investment in Pakistan. Islamabad: Sustainable Development Policy Institute. http://hdl.handle.net/11540/6822 . Accessed 11 April 2021.

Ahmed, N., \& Hyder, K. (2006). Gender inequality and trade liberalization: a case study of Pakistan. MPRA Paper 16252. Munich: MPRA.

Akhtar, S. 2011. Searching for the invisible workers: a statistical study of home based workers in Pakistan. Islamabad: ILO.

Akram-Lodhi, A.H. 1996. 'You are not excused from cooking': peasants and the gender division of labor in Pakistan. Feminist Economics 2 (2): 87-105.

Arshad, M. 2011. Does money matter for women's empowerment A study of the Benazir Income Support Program (BISP) Pakistan. The Hague: International Institute of Social Studies of Erasmus University Rotterdam (ISS).

Asian Development Bank (ADB). (2014). ADB's support for Inclusive Growth. Manila: ADB. 
Balagamwala, M., and H. Gazdar. 2011. Strategic engagement abroad and labour non-markets at home: Globalisation and employment in Pakistan. Karachi: Collective for Social Science Research.

Benería, L., and G. Sen. 1981. Accumulation, reproduction, and" Women's Role in Economic Development": Boserup revisited. Signs 7 (2): 279-298.

Berg, J. 2013. Growth, Distribution, Employment and Poverty, in S. Cazes, and S. Verick, eds. 2013. Perspectives on labour economics for development, pp. 39-62. Geneva: ILO.

Blau, F.D. 2014. Comment on 'The Female Labor Force and Long-run Development: The American Experience in Comparative Perspective.' In Human Capital in History: The American Record, ed. L. Platt Boustan, C. Frydman, and R.A. Margo, 198-203. Chicago: University of Chicago Press.

Borjas, G. 2010. Labor economics, 5th ed. Boston: McGraw-Hill/Irwin.

Boserup, E. 1970. Women's role in economic development. London: Allen and Unwin.

Çağatay, N., and Ş Özler. 1995. Feminization of the labor force: The effects of long-term development and structural adjustment. World Development 23 (11): 1883-1894.

Chaudhury, N., and D. Parajuli. 2010. Conditional cash transfers and female schooling: The impact of the female school stipend programme on public school enrolments in Punjab, Pakistan. Applied Economics 42 (28): 3565-3583.

Chun, J.J. 2016. Organizing across divides: Union challenges to precarious work in Vancouver's privatized health care sector. Progress in Development Studies 16 (2): 173-188.

Danish, M. H., Tahir, M. A., \& Azeem, H. S. (2017). Impact of agriculture subsidies on productivity of major crops in Pakistan and India: A case study of fertilizer subsidy. https://peri.punjab.gov.pk/system/files/IMPACT\%20OF\%20AGRICULTURE\%20SUBSIDIES\%20ON\%20PRODUCTIVITY\% 20 OF $\%$ 20MAJOR $\%$ 20CROPS $\% 20$ IN $\%$ 20PAKISTAN $\% 20$ AND $\% 20$ INDIA $\% 20$ A $\% 20$ CASE $\%$ 20STUDY\%20OF\%20FERTILIZER\%20SUBSIDY.pdf. Accessed on 11 April 2021.

Desai, S., and O. Joshi. 2019. The paradox of declining female work participation in an era of economic growth. The Indian Journal of Labour Economics 62 (1): 55-71.

Easterly, W. (2001). The political economy of growth without development: a case study of Pakistan. Paper for the Analytical Narratives of Growth Project, Kennedy School of Government, Harvard University. Cambridge, MA: Harvard University.

Elson, D. 1999. Labor markets as gendered institutions: equality, efficiency and empowerment issues. World Development 27 (3): 611-627.

Esquivel, V. 2017. Efficiency and gender equality in growth theory: simply add-ons? Canadian Journal of Development Studies/revue Canadienne D'études Du Développement 38 (4): 547-552.

Finance Division - Government of Pakistan, 2010. Agriculture. Available at http://www.finance.gov.pk/ survey/chapter_10/02_agriculture.pdf. Accessed on 11 April 2021.

G20 (2018). Fostering opportunities for an inclusive, fair and Sustainable Future of Work. Declaration of the G20 Employment Ministerial Meeting. Mendoza: G20.

Goldin, C. (1994). The U-shaped female labor force function in economic development and economic history. Working Paper No. 4707. Cambridge, MA: NBER.

Government of Pakistan (2004). Pakistan decent work country programme. Islamabad: Government of Pakistan.

Hill, E. 2014. Women's employment as a barometer of 'inclusive growth': how well is India doing? In Inclusive growth and development in the 21st century: a structural and institutional analysis of China and India, ed. D. Dutta, 219-241. Singapore: World Scientific Publishing.

Hirway, I. 2012. Inclusive growth under a neo-liberal policy framework: Some critical questions. Economic and Political Weekly 47 (20): 64-72.

Hirway, I. 2015. Unpaid work and the economy: Linkages and their implications. Indian Journal of Labour Economics 58 (1): 1-21.

Husain, I. (2007). Pakistan's growth experience 1947-2007. http://ishrathusain.iba.edu.pk/speeches/Pakis tan_s_Growth_Experience_1947-2007.pdf. Accessed 11 April 2021.

ILO (2011). Decent work country programme. Islamabad: ILO Country Office for Pakistan.

International Conference of Labour Statisticians (ICLS). 2018. Resolution concerning statistics on work relationships. Geneva: ILO.

International Labour Organization (ILO). 2018. Women and men in the informal economy: A statistical picture, 3rd ed. Geneva: ILO.

Islam, R. (2014). Human capital and inclusive growth: the challenges for Bangladesh. Paper for presentation at the Bangladesh Economists' Forum Conference, 21-22 June 2014, Dhaka, Bangladesh. 
Islam, R. 2019. Labour market outcomes and inclusive development: experiences of South Asian countries. In Growth, disparities and inclusive development in India, ed. R.P. Mamgain, 75-102. Singapore: Springer.

Jayaweera, S. 1997. Higher education and the economic and social empowerment of women-The Asian experience. Compare 27 (3): 245-261.

Jha, P. 2007. Guaranteeing elementary education: a note on policy and provisioning in contemporary India. Journal of South Asian Development 2 (1): 75-105.

Kabeer, N. 2005. Gender equality and women's empowerment: a critical analysis of the third millennium development goal 1. Gender \& Development 13 (1): 13-24.

Kabeer, N. (2012). Women's economic empowerment and inclusive growth: labour markets and enterprise development. Discussion Paper 29/12. London: Centre for Development Policy and Research.

Kabeer, N. 2016. Gender equality, economic growth, and women's agency: the "endless variety" and "monotonous similarity" of patriarchal constraints. Feminist Economics 22 (1): 295-321.

Kannan, K., and G. Raveendran. 2009. Growth sans employment: a quarter century of jobless growth in India's organised manufacturing. Economic and Political Weekly 44 (10): 80-91.

Kapsos, S. (2005). The employment intensity of growth: trends and macroeconomic determinants. Employment Strategy Papers 12. Geneva: ILO.

Kazi, S. 1999. Gender inequalities and development in Pakistan. In Fifty Years of Pakistan's Economy: Traditional Topics and New Concerns, ed. S.R. Khan, 376-414. Karachi: Oxford University Press.

Kemal, A.R. 2006. Key issues in industrial growth in Pakistan. Lahore Journal of Economics 11: 49-74.

Kemal, A.R., and S.M. Naseem. 1994. Structural adjustment, employment, income distribution and poverty [with comments]. The Pakistan Development Review 33 (4): 901-914.

Khan, A. 2007. Women and paid work in Pakistan. Karachi: Collective for Social Science Research.

Khan, M.H. 2012. The political economy of inclusive growth. In Promoting inclusive growth: challenges and policies, ed. L. de Mello and M.A. Dutz, 15-53. Paris: OECD Publishing.

Khan, A. (2012). Major problems of agricultural sector of Pakistan. Economics and education. http:// ahsankhaneco.blogspot.com/2012/04/major-problems-of-agricultural-sector.html. Accessed 11 April 2021.

Khattak, S.G. 2002. Subcontracted work and gender relations: the case of Pakistan. In The hidden assembly line: gender dynamics of subcontracted work in the global economy, ed. R. Balakrishnan, 35-62. Bloomfield: Kumarian Press Bloomfield, CT.

Klasen, S., and F. Lamanna. 2009. The impact of gender inequality in education and employment on economic growth: new evidence for a panel of countries. Feminist Economics 15 (3): 91-132.

Majid, H. (2011, January 20). The economics of gender inequality in Pakistan. Dawn.

Majid, H. 2020. Female labor force participation in Pakistan. In Voices on South Asia-Interdisciplinary perspectives on women's status, challenges and futures, ed. E.J. Flatt, V.S. Murali, and S. Tier. Singapore: World Scientific.

Majid, H., \& Zahir, H. 2013. Climate change and the impact on farmer productivity: the role of socioeconomic vulnerability in Pakistan. IDRC-CRDI Climate Change in Pakistan: Working Paper Series No. 1. Ottawa: IDRC.

Mason, K. O., and Smith, H. L. 2003. Women's empowerment and social context: Results from five Asian countries. Gender and Development Group, World Bank, Washington, DC.

Ministry of Finance. 2018. Pakistan economic survey 2017-18. Islamabad: Ministry of Finance.

Mitra, A., J.T. Bang, and A. Biswas. 2015. Gender equality and economic growth: is it equality of opportunity or equality of outcomes? Feminist Economics 21 (1): 110-135.

Murgai, R., M. Ali, and D. Byerlee. 2001. Productivity growth and sustainability in post-Green Revolution agriculture: the case of the Indian and Pakistan Punjabs. The World Bank Research Observer 16 (2): 199-218.

Nazir, M.A. (2017). Invisibility of women's productive work in labour statistics - special reference to Pakistan. MA Thesis. The Hague: ISS.

Niimi, Y. (2009). Gender equality and inclusive growth in developing Asia. ADB Economics Working Paper Series 186. Manila: ADB.

Olivetti, C. (2013). The female labor force and long-run development: the American experience in comparative perspective. Working Paper 19131. Cambridge, MA: NBER.

Organisation for Economic Co-operation and Development (OECD). 2018. Opportunities for all: the framework for policy action on inclusive growth. Paris: OECD.

Osmani, S.R. 2006. Exploring the employment nexus: The analytics of pro-poor growth. In Fighting poverty: The development-employment link, ed. R. Islam. Boulder: Lynne Rienner. 
Pakistan Bureau of Statistics (PBS) (2019). Macro economic indicators. http://www.pbs.gov.pk/sites/ default/files//tables/Table-1_0.pdf. Accessed on May 1, 2020.

PBS (2010) Pakistan standard industrial classification (all economic activities) PSIC Rev. 4 (2010). Islamabad: PBS.

PBS. 2011. Labour force survey 2010-11. Islamabad: PBS.

PBS. 2015. Labour force survey 2014-15. Islamabad: PBS.

PBS. 2016. Pakistan social and living standards measurement survey (2014-15). Islamabad: PBS.

PBS. 2018. Labour force survey 2017-18. Islamabad: PBS.

Pearson, R. 2007. Reassessing paid work and women's empowerment: lessons from the global economy. In Feminisms in development: Contradictions, contestations and challenges, ed. A. Cornwall, E. Harrison, and A. Whitehead, 201-213. London, New York: Zed Books.

Pervaiz, Z., M.I. Chani, S.A. Jan, and A.R. Chaudhary. 2011. Gender inequality and economic growth: A time series analysis for Pakistan. Middle-East Journal of Scientific Research 10 (4): 434-439.

Planning Commission (Pakistan). 2014. Pakistan Vision 2025 and the 11th five year plan. Islamabad: Planning Commission of Pakistan.

Raynor, J., K. Wesson, and M. Keynes. 2006. The girls' stipend program in Bangladesh. Journal of Education for International Development 2 (2): 1-12.

Roots for Equity. 2011. Unacknowledged treasures: the home-based women labour of Pakistan. Karachi: Roots for Equity.

Sabir, M., and Z. Aftab. 2007. Dynamism in the gender wage gap: evidence from Pakistan. The Pakistan Development Review 46 (4 Part II): 865-882.

Sathar, Z. A., and Kazi, S. 1990. Women, work and reproduction in Karachi. International Family Planning Perspectives, pp. 66-80.

Sathar, Z.A., and S. Kazi. 2000. Women's autonomy in the context of rural Pakistan. The Pakistan Development Review 16 (2): 89-110.

Sathar, Z., N. Crook, C. Callum, and S. Kazi. 1988. Women's status and fertility change in Pakistan. The Population and Development Review 14 (3): 415-432.

State Bank of Pakistan (SBP) (2018). Economic Review 2018. Karachi: SBP. http://www.sbp.org.pk/repor ts/annual/arFY19/Chapter-01.pdf. Accessed 11 April 2021.

Seguino, S. 2000. Accounting for gender in Asian economic growth. Feminist Economics 6 (3): $27-58$.

Seguino, S. 2016. Global trends in gender equality. Journal of African Development 18: 1-30.

Seguino, S. 2020. Engendering macroeconomic theory and policy. Feminist Economics 26 (2): 27-61.

Seguino, S., and C. Grown. 2006. Gender equity and globalization: macroeconomic policy for developing countries. Journal of International Development 18 (8): 1081-1104.

Sen, A. (1987). Gender and cooperative conflicts. Working Paper No. 1342. Helsinki: WIDER.

Siddiqui, R., S. Hameed, R. Siddiqui, and N. Akhtar. 2003. Gender and adjustment policies: Evidence from Pakistan. In Tracking gender equity under economic reforms: Continuity and change in South Asia, 1st ed., ed. S. Mukhopadhyay and R. Sudarshan, 153-195. New Delhi/Ottawa: Kali for Women/IDRC.

Siegmann, K.A., and N. Shaheen. 2008. Weakest link in the textile chain. Pakistani cotton pickers' bitter harvest. The Indian Journal of Labour Economics 51 (4): 619-630.

Smith-Miles, K. 2011. Exploratory data analysis. In International encyclopedia of statistical science, ed. M. Lovric, 486-488. Berlin, Heidelberg: Springer-Verlag.

Tam, H. 2011. U-shaped female labor participation with economic development: some panel data evidence. Economics Letters 110 (2): 140-142.

Tejani, S. 2016. Jobless growth in India: An investigation. Cambridge Journal of Economics 40 (3): 843-870.

United Nations. 2015. Draft outcome document of the United Nations summit for the adoption of the post2015 development agenda. New York: UN.

United Nations Development Programme (UNDP). 2017. UNDP's strategy on inclusive and sustainable growth. New York: UNDP.

Van Staveren, I. 2013. An exploratory cross-country analysis of gendered institutions. Journal of International Development 25 (1): 108-121.

World Bank. 2009. What is inclusive growth? Washington, DC: World Bank.

World Bank. 2011. World development report 2012: gender equality and development (2011). Washington, DC: World Bank.

World Bank (2020). World development indicators. https://databank.worldbank.org/source/world-devel opment-indicators. Accessed 11 April 2021. 
World Economic Forum. 2019. The global gender gap report 2020. Cologny: World Economic Forum.

Publisher's Note Springer Nature remains neutral with regard to jurisdictional claims in published maps and institutional affiliations. 